\title{
Juno among the Counterfeiters: Tragedy vs. Comedy in Dante's Inferno 30
}

Canto 30 of the Inferno begins with an unusually extended simile, the longest in the Commedia:

Nel tempo che Iunone era crucciata per Semelè contra 'I sangue tebano, come mostrò una e altra fiata,

Atamante divenne tanto insano, che veggendo la moglie con due figli andar carcata da ciascuna mano, gridò: "Tendiam le reti, sì ch'io pigli la leonessa e' leoncini al varco"; e poi distese i dispietati artigli, prendendo l'un ch'avea nome Learco, e rotollo e percosselo ad un sasso; e quella s'annegò con l'altro carco.

E quando la fortuna volse in basso l'altezza de' Troian che tutto ardiva, sì che 'nsieme col regno il re fu casso,

Ecuba trista, misera e cattiva, poscia che vide Polissena morta, e del suo Polidoro in su la riva del mar si fu la dolorosa accorta, forsennata latrò sì come cane; tanto il dolor le fé la mente torta. Ma né di Tebe furie né troiane si vider mäi in alcun tanto crude, non punger bestie, nonché membra umane, quant' io vidi in due ombre smorte e nude, che mordendo correvan di quel modo che 'l porco quando del porcil si schiude. (1-27)

Almost unanimously the commentaries record a puzzled reaction. Bosco points out the "scarsa rispondenza" between the figures of Atamante and Hecuba and those of Gianni Schicchi and Mirra compared 
to pigs coming out of the sty: "Atamante, Ecuba e il porco coesistono malamente in una sola molecola fantastica" (425). Momigliano states: "Dal classico siamo piombati nel grottesco: tragicamente bello l'uno, plebeamente stupendo l'altro; ma non fusi l'uno con l'altro" (613). Emilio Bigi admits to an impression of "dissonanza" and "sproporzione" between the simile and the rushing in of the two falsifiers: "E ci si chiede perché mai Dante abbia voluto introdurre questa rapida e brutale descrizione mediante un così vistoso indugio su due episodî illustri di mitologica pazzia" (1064). Contini makes the point even more strongly: "Ma per chi tanto lusso di ricordi illustri, di regie sventure? . . . La cronaca nera e il gazzettino rosa, i pettegolezzi di farmacia, le diffamazioni municipali . . . sono fra gl'ingredienti capitali della vasta contaminatio di Dante" ("Sul XXX" 449).

Let us examine the few solutions offered to explain the presence of the simile. Sapegno believes that it expresses "la disposizione distaccata e curiosa del pellegrino" as he examines the contemptible sins of this bolgia. Bigi sees in it a "precisa funzione morale" since Dante states in each mythological scene the "colpa religiosa" and the ensuing "ineluttabile effetuarsi di una terribile punizione divina." The two myths would make explicit the presence of the "giudizio divino" in the torments of the counterfeiters (1067-68). In other words, the two sets of punishments-in the myths and in the tenth bolgia - would be the product of the same kind of divine justice at work and the Christian God would be equated with the vengeful Juno-an unacceptable hypothesis. Besides, if the simile had this "moral function," one wonders why Dante would feel the need to justify divine punishment only in the case of the falsifiers and not for any other of the damned souls.

It is difficult to perceive the necessary tertium comparantionis between the two terms of the comparison. The protagonists of the mythological stories are undone by a vengeful goddess through no fault of their own; they bear no conceivable resemblance to the sinners to whom they are compared, either in terms of guilt or of the sin punished in this bolgia. Let us remember that the simile, though placed at the beginning of the canto, is inserted into the episode of the falsifiers which has started in the previous canto, and which then resumes in canto 30 . The simile thus constitutes a break in the 
plebeian and ribald atmosphere of the tenth bolgia, an odd interlude of royalty and tragedy in the middle of a mostly low-class group of petty sinners. In a way, it is the opposite of what Dante does in Purgatorio 6 where the zara simile introduces a jarring note of coarse venality after the dramatic stories of noble souls in Purgatorio 5. In either case the result is an imbalance of tone and a startling contrast of contents and style registers. What emerges clearly in canto 30 is a mismatching of expressive means, a promiscuous mixture of high and low tones, a lack of connection between the mythological exempla and the infernal reality. One of the most vulgar cantos of the poem is given one of the loftiest exordia.

Moreover, as Bosco observes in his commentary:

non si scorge la ragione dell'avere accomunato il re tebano e la regina troiana: nulla essi hanno di comune tra loro, se non la pazzia. Se questa fosse il denominatore comune, essa dovrebbe essere la malattia anche di Gianni e di Mirra . . . e invece il poeta parla più volte di rabbia. (425)

This is an important point: if there is no connection between the vehicle and the tenor of the simile, is there a common denominator at least between the two protagonists of the mythological stories?

Dante takes his material from Ovid's Metamorphoses. The Athamas episode is described in Book 4 (416-562), and Dante's reference to Juno's wrath against the Theban blood is indeed based on Ovid's descriptions of her irate jealousy of Semele. In the Hecuba episode (13.399-575), conversely, Ovid does not ascribe her fate to Juno's hatred. Accordingly, Dante does not mention Juno in the lines he devotes to Hecuba's sad plight.

It is, however, my contention that the common denominator between Athamas and Hecuba is indeed Juno's revenge. Dante, for reasons not immediately apparent, seems to have placed the whole episode of the falsifiers under the shadow of Juno's wrath. In the previous canto, when he sees the punishment of these sinners, he introduces a first simile on the same subject:

Non credo ch'a veder maggior tristizia fosse in Egina il popol tutto infermo, quando fu l'aere si pien di malizia, che li animali, infino al picciol vermo, cascaron tutti, e poi le genti antiche, secondo che i poeti hanno per fermo, 
si ristorar di seme di formiche; ch'era a veder per quella oscura valle languir li spirti per diverse biche.

In this case, as in that of Hecuba, Dante does not mention Juno as the cause of the catastrophe. Yet, in Ovid's version of the myth (7.523-660), King Aeacus says: "A dire pestilence came on my people through angry Juno's wrath, who hated us for that our land was called by her rival's name."1 Thus the fact that Dante does not refer to Juno in the Hecuba exemplum either, does not necessarily mean that he sees her fate as unconnected with Juno. Although Dante explicitly mentions Juno only in the first line of canto 30 , he seems to have her wrath in mind in all three legends of Aegina, Thebes and Troy. If Ovid attributes to Juno's revenge only the undoing of Aegina and Athamas, we can find Juno's involvement in the Trojan tragedy elsewhere, specifically in Dante's principal and constant source: Virgil.

Dante, who knows the Aeneid "tutta quanta" (Inf. 20.114), must of course be aware of the fact that the Virgilian poem ascribes to Juno's intervention not only the obstacles facing Aeneas throughout, but also the fall of Troy. From the very beginning of his epic, Virgil bemoans the enmity of Juno: "cruel Juno's unforgiving wrath."2 After asking the Muse to tell him the cause for which the "regina deum" could drive a man remarkable for his "pietas" to so many perils, he wonders: "Can resentment so fierce dwell in heavenly breasts?" And more explicitly he explains further down:

The daughter of Saturn . . . mindful of the old war which erstwhile she had fought at Troy for her beloved Argos-not yet had the cause of her wrath and her bitter sorrows faded from her mind: deep in her heart lie stored the judgment of Paris and her slighted beauty's wrong, her hatred of the race and the honors paid to ravished Ganymede ... (Aen. 1.23-28) ${ }^{4}$

These and other examples, too numerous to quote, clearly show Virgil's choice of the root of all the ills that had befallen Troy and that will afflict Aeneas: Juno's undying wrath and burning desire for revenge. As R. W. Johnson observes (14), Juno's anger is close to being the central theme of the Aeneid. It underlies the whole story of Aeneas and recurs insistently until the end of the poem, conferring upon it a dark shadow of cruelty. 
Dante's digression in Inferno 30 , with the account of the dire effects of Juno's vindictiveness, as well as his reference in the Vita Nuov'a to Juno as "una dea nemica de li Troiani" (25.9), may suggest that he shared the Aeneid's concern with the theme of Juno's wrath. Like Virgil before him, Dante too seems to have been struck by the irrational and all-encompassing hatred of Juno, not just towards her direct rivals for Jupiter's love, but also towards all of their immediate families, descendants, or even their whole races. She exterminates the entire population of Aegina, just as she destroys Semele's sister and kin and conspires to bring about the fall of Troy and thus the annihilation of Paris's family.

Juno may represent, in Dante's eyes, the essence of the pagan conception of divine power, arbitrarily exercised to evil and unjust ends. It is therefore unreasonable to believe, as some critics do, that Dante could equate the punishing justice of the Christian God with the atrocities of Juno indiscriminately sowing destruction on her path to revenge. If anything, Dante is showing how antithetical to the true God's justice is the pagan vengeance inflicted upon those who essentially are innocent victims. Let us remember that, when entering the tenth bolgia Dante says:

e allor fu la mia vista più viva giù ver' lo fondo, là 've la ministra

de l'alto Sire infallibil giustizia

punisce i falsador che qui registra.

(Inf. 29.54-57)

It would be surprising indeed if Dante deemed necessary to call on Juno's help to show the fairness of what he himself defines as the infallibil giustizia of l'alto Sire.

Of course, if we reject that hypothesis, we still are left with the problem: what is the purpose of the simile in Inferno 30? The other explanations-ironic detachment, display of erudition-are as easy as they are implausible. Undoubtedly, an imitation of Ovid and. in my opinion, Virgil seems to be a reasonable justification for the simile. Dante at times admits to his own desire of emulating his illustrious predecessors, as he does for example in Inferno 25.94-99. But this could only be the beginning of an explanation.

Bigi sees the simile elaborated with an explicit rhetorical effort, even if "not always poetically valid." In my opinion, Contini seems 
to be more to the point when he speaks of the "andatura prosaica dell'elocuzione" (448). If we place side by side this simile with the extended comparison we find in Inferno 24.1-21, we can but notice the striking difference between the two passages with respect to their rhetorical devices. The first six lines of the villanello simile are laden with circumlocutions, personifications, metaphors, literary allusions and conceits. There is nothing comparable in Inferno 30.1-27. Here the language is simple, even pedestrian, as in line 10 ("prendendo l'un ch'avea nome Learco"), not too elegant, as in line 15 ("il re fu casso"). Besides the few elements noted by Bigi, I would only add the presence of a few alliterations, most notably in line 9: "distese i dispietati artigli." But there are no rhetorical figures as in the first segment of the villanello simile or even in the general language of the Commedia.

Dante would seem to have deliberately refrained from giving an ornate vesta to this trope, establishing an almost peculiar contrast between the high tone of the content and the "prosaic" style of the elocution. But why? If what Dante is doing is setting himself in competition with Ovid and Virgil, he may be suggesting that he is able to use their same lofty material in a plain, unadorned language. That there is a certain polemical intent in his citation of classical sources may perhaps be manifest in the first "Juno" simile (Inf. 29.58-66). When he relates that the exterminated population of Aegina was restored "di seme di formiche," he interjects the line: "secondo che i poeti hanno per fermo" (63). That "per fermo" undeniably sounds sarcastic since it precedes the unlikely dénouement of a human generation from the seed of ants. ${ }^{6}$ But is Dante just trying to make a not too novel point about the untruthfulness of the classical poets? Moreover, the two other examples concerning Athamas and Hecuba are not vitiated by the same character of improbability.

Considered by itself, of course, the simile of canto 30 presents no interpretive difficulty. It is the context that makes it appear wrong and puzzling. The downfall of Theban and Trojan royal houses is evoked to set off what Bosco appropriately calls "peccati da commedia" (425). Perhaps it is in this remark that we can find a solution to the problem.

I have already argued elsewhere that Dante is concerned with establishing a contrast between Virgil's alta tragedia and his own 
comedia. ${ }^{7}$ Virgil had used the theme of Juno's wrath to introduce and develop his epic poem, from the fall of Troy to the violent battles of Italy. Tales about tragedies of cataclysmic proportions, mournful individual deaths, the destiny of a race, the future of Rome and of the world, are the subjects of the Aeneid through which the vindictive anger of the goddess is interwoven. Dante selects the same starting point of Juno"s resentment to tell us about two infuriated "ombre" running in the fashion of the "porco quando del porcil si schiude." What originates alta tragedia in Virgil gives way to low comedy in Dante.

What may also strike us as unusual is the identity of these souls thus paired: one is Mirra, a character from classical antiquity, who had pretended to be someone else in order to lie incestuously with her father. The other ombra is Gianni Schicchi, a man from modern times. His sin of impersonation to draw a fake will and thus gain a mule for himself can only elicit an amused reaction. He is more of a joker, a trickster, than an evil sinner. By having him defined as a "folletto," Dante signals the playful and mischievous character of the Florentine falsifier. It is hard to take him seriously. There is surely no madness in him or in his rather modest greed. His farcical story of course clashes with the darkness of desperate and unnatural love surrounding "l'anima antica / di Mirra scellerata," where even the words used to describe the soul confer on her an aura of tragic dignity in evil. What Dante takes away when he assimilates her to a hog let out of the sty and therefore, as Singleton indicates (549), running on all fours, he gives back in the lines identifying her. But, by pairing her with Gianni Schicchi, he reinforces her debasement. Tragedy racing along with comedy on hands and feet can hardly preserve its original loftiness. What Dante has done at the beginning of the canto, comparing Athamas and Hecuba to the two "ombre smorte e nude" moving in a hog-like fashion, he continues doing in the subdivision of these same two spirits. Again he places high and low side by side and, in the contamination, comedy wins over and blankets out any possible effect of awe and terror.

A different kind of contrast is established for the central character of the canto. Master Adam appears as a grotesque figure. Yet, the language used to introduce the new soul is solemn in signaling the beginning of a new episode: "Io vidi un ..." (49). The 
deformities caused by his dropsy are horrifying. Yet, the description is formulated by means of rare and difficult expressions and rhymes in a juxtaposition of the refined (a guisa di lëuto, dispaia, rinverte) and the vulgar (anguinaia, forcuto, ventraia).

Master Adam's speech, with a single exception, is couched in an elevated language:

"O voi che sanz'alcuna pena siete, e non so io perché, nel mondo gramo," diss'elli a noi, "guardate e attendete a la miseria del maestro Adamo; ...."

(Inf. 30.58-61)

As generally noted, these words echo Jeremiah's Lamentations: "O vos omnes qui transitis per viam, attendite et videte / si est dolor sicut dolor meus" (1.12). In a sonnet of the Vita Nuova Dante had already paraphrased the same passage: "O voi che per la via d'Amor passate, / attendete e guardate / s'elli è dolor alcun, quanto 'I mio, grave" (7.3). It is important to remember that the sorrow Dante refers to on that occasion is only a pretense: the lady Dante had adopted as a schermo to hide his true love for Beatrice had left Florence and, afraid that his ruse would be unmasked if he displayed no sadness, he wrote that sonnet. To feign grief, Dante thus resorted to the hyperbole of Jeremiah's Lamentations, as though only an exaggerated display of despair could lend credibility to his false complaint. In Inferno 28 Bertran de Born addresses Dante by resorting also to Jeremiah:

... "Or vedi la pena molesta, tu che, spirando, vai veggendo i morti: vedi s'alcuna è grande come questa ...."

(Inf. 28.130-32)

Bertran paraphrases only the last part of the Biblical passage ("videte / si est dolor sicut dolor meus") while Master Adam only the first part: "O vos omnes qui . . ., attendite et videte ..." It would almost seem as though the speeches of Bertran and Master Adam complemented each other. But are they meant to be a sincere expression of sorrow or is their going back to so noble a source as a Lamentation of Jeremiah rhetorical affectation and hence a signal that their suffering is not to be taken too much at heart, as Dante's own was not in that episode of the Vita Nuova? 
The Biblical references continue in the next lines: "io ebbi, vivo, assai di quel ch'i' volli, / e ora, lasso!, un gocciol d'acqua bramo" (62-63). It is now Luke's parable about the rich man and the poor Lazarus that is evoked (16.23-24). The wealth of citations from classical and Biblical sources increases the contrast with the venal milieu of petty falsifiers and counterfeiters.

Master Adam's speech then shifts to a lyrical tone:

Li ruscelletti che d'i verdi colli del Casentin discendon giuso in Arno, faccendo i lor canali freddi e molli, sempre mi stanno innanzi, e non indarno, ché l'imagine lor vie più m'asciuga che 'I male ond'io nel volto mi discarno.

La rigida giustizia che mi fruga tragge cagion del loco ov'io peccai a metter più li miei sospiri in fuga.

(Inf. 30.64-72)

The rhetorical virtuosity continues, now with a bow to Virgil. As noted by Singleton (555) among others, the "canali freddi e molli" is an erudite allusion to Eclogues 10.42: "Hic gelidi fontes, hic mollia prata." It is somehow incongruous that this ludicrous figure should address his desperate desire for water in such poetic and delicate words, while recognizing at the same time the justness of divine punishment. $^{8}$

The last part of Master Adam's speech centers on his violent hatred for the counts Guidi of Romena, Guido, Alessandro and Aghinolfo, who had instigated him to counterfeit the gold florin of Florence. To have his revenge by seeing them in Hell too, he would give up a whole fountain. While the counterfeiter's vengeful rage has something awesome about it, we may question Dante's choice of the episode because of the thoroughly negative light it projects on a family whose hospitality he had benefited from. Besides, Alessandro and Aghinolfo had fought in 1303 and 1304 (Aghinolfo also in 1305, Alessandro having died probably in 1304) against Florence on behalf of the White exiles, among whom was Dante himself. One or the other of the two brothers had even been the leader of the rebel troops. Later, Aghinolfo had been a faithful supporter of Henry VII's expedition in Italy between 1310 and 1313, and he had been among the first Italian lords to pledge loyalty to the emperor. Dante met 
Aghinolfo in Pisa in the spring of 1312 at the court of Henry VII. ${ }^{9}$ Sapegno explains away this negative judgment in Inferno 30 merely as proof that Dante's superior moral stance sub specie aeternitatis overrides earthly allegiances (444). It might however also be possible that Dante is signaling to us a more profound change in his views both with regard to the initial enterprise of the White exiles against Florence-what after all was civil war brought by them and by himself against his own city - and with regard to the failed enterprise of the emperor, another war on Florence advocated and wished for by him at the time. ${ }^{10}$

It is in any case hard to be sure of Dante's intentions as he does not reveal any personal feelings when hearing Master Adam's outburst against the Conti Guidi. But it is also important to note that Dante does not show either any irritation when the counterfeiter, at the beginning of his speech, rather unpleasantly, says: "O voi che sanz'alcuna pena siete, / e non so io perché, nel mondo gramo" (5859). That "non so io perché" is rather insulting. Let us remember that, on a previous occasion, a much more harmless question had elicited an irate riposte from Dante. In Inferno 8.33, Filippo Argenti asks Dante: "Chi se' tu che vieni anzi ora?" Whether Dante interpreted the question as a slight or was just being infected with the sin of the wrathful, he responds with angry and contemptuous words. But when Master Adam interjects his spiteful remark in the only rhetorical lapse of his address, Dante does not react. At the end of the soul's speech, Dante merely asks about the two other damned lying close by.

Here we have another striking juxtaposition. Potiphar's wife, she who had falsely accused Joseph of attempted seduction, is seemingly given the role of representing the world of the Bible in this continuing contamination. ${ }^{11}$ The "falso Sinon greco di Troia" in turn represents classical culture, in an apparent return of the text to the milieu dominating the beginning of the canto. But, at the same time, how debased that culture appears when we see it embodied by Sinon, not so much for what he represents-the quintessential treacherous liar-as for how he now behaves in Hell. While Potiphar's wife remains dignifiedly silent throughout the episode, Sinon engages in an active interchange with Master Adam.

What is extraordinary is that Dante uses this Virgilian creature 
for one of the most heated and coarse quarrels of the Commedia. The two men exchange insults and physical blows as though they were fishmongers in the market place. Forgotten is Master Adam's elegant and refined tone. Even more forgotten is the highly eloquent and vibrantly rhetorical style of Sinon's speech in the Aeneid (2.69194) by which he ensnared the Trojans. Here in Hell Sinon finally is truthful, as the counterfeiter remarks: "Tu di" ver di questo; / ma tu non fosti sì ver testimonio / là 've del ver fosti a Troia richiesto" (112-114). But this truth is now banal and it comes at the cost of the high register he had used in the Latin poem. Through Sinon, Dante places the world of Virgil in direct clash with the small Tuscan world of the counterfeiter and from this contact the Virgilian creature emerges withered.

In order to see the scene in its proper perspective, it may not be superfluous to go over the key role played by Sinon in the fall of Troy. What Sinon achieved is what makes this episode in Inferno 30 so striking and maybe more deserving of our attention than it has so far received. Without Sinon, Ulysses' ingenious ploy of the wooden horse could not have been carried out and Troy would not have been conquered. Sinon was the indispensable link between Ulysses' brilliant conception and its materialization. The whole plan depended on Sinon's eloquence in persuading the Trojans to take the horse into the city. Thus Sinon was no common liar. On his ability to speak lies in the semblance of truth hinged the final issue of the 10-year war and the whole fate of Greece and Troy. Yet, Dante takes this accomplished master of rhetoric and has him humiliated and reduced to silence by a relatively ordinary and little known falsifier of coins in modern Tuscany.

It is true though that, as remarked by Bigi among others (108284), the altercation, vulgar as it may be, is still replete with learned and skilful touches of verbal virtuosity: antitheses ("membra ... gravi, braccio ... sciolto," 107-08), chiastic constructions ("Quando tu andavi ... non l'avei . . ., più l'avei quando coniavi," 109-11; "la bocca tua per $t u o$ mal ..., 125), repetitions, annominationes, circumlocutions (as the famous "specchio di Narcisso"). Oddly perhaps, there is a much greater deployment of rhetorical devices in this debate than in the presentation of the simile opening the canto. As noted by Momigliano (222), the quarrel alternates between the 
two contenders, each being allotted one tercet in a rapid and prompt exchange of wits, until the "larga e vittoriosa conclusione di mastro Adamo," who in fact seemingly wins the contest by monopolizing two tercets at the end and thus having the last word.

It is at this point, while Dante is listening with fascinated attention, that Virgil harshly chides him: "Or pur mira, / che per poco che teco non mi risso!" (131-32). Dante is so upset by Virgil's rebuke that, mortified and embarrassed, he is unable to speak. Virgil, appeased by what he sees as Dante's contrition, quickly pardons him. He concludes his conciliatory speech, and the canto, praising, in Bigi's words, "la crisi purificatrice del discepolo" (1086), and sententiously warning him: "voler ciò udir è bassa voglia" (148). As a result, many critics have interpreted the whole scene as having been engineered by Dante to show his own repudiation of the comic-realistic genre in which he had indulged himself when exchanging the famous tenzone with Forese Donati. Dante would now feel ashamed of that genre and hence be in agreement with Virgil's condemnation of it. ${ }^{12}$ Contini himself adopts such interpretation although noting amusedly the paradox that first Dante allows free rein to the "bassa voglia" by giving it full expression, and only thereafter yields to the control of his "coscienza morale-estetica" ("Sul XXX" 456).

More cautiously, Bosco notes that, after 1300, supposed date of the voyage to the afterworld, Dante was still engaged in the "comicrealistic subgenre" as testified by a tenzone with Cecco Angiolieri. And in the Commedia itself there is still to come Dante's squabble with Bocca degli Abati (Inferno 32.85-123). Bosco hence concludes that Dante considers comic poetry necessary in certain contexts while rejecting it, through Virgil, when it is practised for the sake of mere amusement. Virgil is prodding Dante to concentrate on his vocation, which would supposedly be that of "high" poetry (426-27).

I believe that Dante's message is more complex than what may appear on the surface. There might be here an underlying intent to assert the legitimacy of "comic-realistic" poetry and of the esthetics based on the intermingling of genres of which the whole Commedia itself is composed, alternating between high, middle and low tones. The polemical position implicit in the very title of the poem, setting it in direct contrast with the alta tragedia which is the Aeneid, seems to find one of its more clamorous restatements in Inferno 30. Far from 
repudiating the "comic-realistic" genre of the tenzone, Dante gives it in this canto its most perfected realization, showing the richness of its possibilities, the wealth of rhetorical techniques inherent in its own nature of verbal contest. It is not the substance or contents which determine the quality of a piece of poetry, Dante seems to be suggesting. A tale of sublime tragedies, such as in the initial simile, if expressed in prosaic style does not possess much intrinsic beauty. Conversely, a vulgar brawl between two debased characters can be lifted to an artistic level thanks to the virtuosity of rhetorical devices and skills.

I am aware of the objection to my thesis suggested by Dante's reaction to Virgil's reprimand as described in lines 133-41. But I believe that there is perhaps here a certain mischievous play at work. To try to understand what is happening, we should remember the often made distinction between Dante as character in the poem and Dante as its author. ${ }^{13}$ The character blushes, mortified by the rebuke, and sheepishly displays his desire to apologize, thus eliciting forgiveness from Virgil who, placated, generously comforts him.

But that this is not the whole story may be seen from a few hints provided in the scene. First of all, by his very words, Virgil reveals an uncharacteristic loss of control over himself, something that critics have generally neglected to note when praising Virgil's intervention. Only Bigi observes that Virgil's "energica rampogna" is still "fortemente legata al tono e allo stile della scena precedente" and that the phrase "Or pur mira!" is "quasi popolaresco" (1085). But, while aware of how the tone is atypical of the elegant poet, Bigi limits himself to discerning in this last section of the canto only a "progressivo annobilimento" of its means of expression. He does not question the reasons or need for Virgil's temporary lapse from his customary dignity and propriety of language.

While it is not the first time that Virgil expresses disapproval of Dante (see for instance Inferno 7.70-72; 20.27-30), he displays here an unusually intense anger made evident by his threat of a "rissa" with Dante and even more by the slightly irregular syntax of the phrase ("che per poco che teco") and by the cacophonous sounds (che co-che co) in addition to the "r's" of "Or pur mira." It is almost as though Virgil himself had been infected with the vulgarity of the scene and reacted accordingly, almost eager to enter himself into a 
scuffle with Dante in imitation of the one between Master Adam and his own Sinon, and, in addition, forgetting his mastery of linguistic rules. The very choice of the verb rissare, from fare rissa (where rissa means brawl, with exchange of insults and blows) reveals a surprisingly excitable Virgil. To reproach Dante for listening to an altercation by adopting a similarly irate tone is, to say the least, illogical, and especially inappropriate for the "savio duca."

One wonders how the scene could have developed had Dante answered back in a similar tone. Fortunately, he holds his peace. But we can detect a sense of pained surprise in Dante's wording of line 133, "Quand'io 'l senti' a me parlar con ira," as though he really had not expected that Virgil should speak to him in anger. Besides, it is interesting that, in describing his own subsequent state, Dante resorts to the same wealth of annominationes that had characterized the exchange between Master Adam and Sinon and, earlier, Griffolino's speech (lines 39, 41, 44 and 45):

Qual è colui che suo dannaggio sogna,

che sognando desidera sognare,

sì che quel ch'è, come non fosse, agogna,

tal mi fec'io, non possendo parlare,

che disïava scusarmi, e scusava

me tuttavia, e nol mi credea fare.

(Inf. 30.136-41)

Dante, therefore, even after his master's reproach, is still resorting to the style of the damned souls, but only with respect to its precious literary aspect and not to its quarrelsome and plebeian tone which is instead adopted by Virgil when he gives vent to his wrath.

If we accept the premise that Dante really aims at defending the genre censured by Virgil, we may then see falling into place the heterogeneous and mutually contradictory pieces of the puzzle that this canto is, and we can see it form a comprehensible and logical whole. The insistent succession of jarringly contrasting juxtapositions of highs and lows, of tragedy and comedy, of classical characters and farcical pranksters, of an impersonator for love and a falsifier for a mule, of a prevaricator causing the fall of a kingdom and a counterfeiter of greed, of elegant allusions to Biblical or literary texts and tavern-like scuffles: all of this mingling is indeed difficult to explain if we take Virgil's condemnation of the tenzone 
as Dante's own. But the comaminatio can find its justification once we recognize the struggle Dante is pursuing in the defence of his unprecedented attempt to create a poetry which follows none of the classical canons of stylistic hierarchics, of taste and decorum, of the rigid limits restricting what is permissible within a particular mode and what is not. Dante seems to be rejecting here once and for all the strictures of a consistently high tone in favour of the freedom to let low comedy infiltrate the text and to interweave a multiplicity of levels in an enriching dialectic of styles.

Dante's polemic is probably addressed in general to an educated audience. Within the text itself, however, it is primarily and unavoidably directed against Virgil as the representative par excellence of alta tragedia and, hence, as the natural adversary and authoritative antagonist of the product he is witnessing at first-hand, the foremost obstacle that Dante has to surmount in his novel enterprise. In a way, Dante is directly confronting Virgil both by exposing him to this dizzying interchange of styles and, even more, by using one of Virgil's own creatures to be the interlocutor of a tenzone with a near-contemporary of Dante from Dante's own territory. No wonder that Virgil is perturbed and angered. When Dante had entered into a squabble with Filippo Argenti in Inferno 8, Virgil, far from rebuking his protégé, had lavished praise on him; and in the next debate, between Dante and Bocca degli Abati (Inferno 32), he abstains from any comment. His position seems to be that these are just matters among men of Dante's own time and place, of no interest to him. His leniency in these cases seems to imply a certain contempt for or lack of concern with what may seem to him to be the vulgarity of Dante's milieu. ${ }^{14}$ But the situation changes when what is at stake is Virgil's own world, contaminated by the clash with the shabby underworld of modern Tuscany. In Virgil's presence, the supremely clever Sinon who, by the sheer power of his brilliant eloquence, had singlehandedly made possible the defeat of otherwise unconquerable Troy, is brought down in turn as the Greek engages in a coarse scuffle and is outwitted by a petty falsifier of coins. Let us also remember that Virgil had probably noticed Master Adam's impertinent allusion to the Aeneid when he says to Sinon: "e sieti reo che tutto il mondo sallo!" (120). It is not flattering for Virgil to see his poem cited by a common criminal. Virgil, thus challenged in his own creation, reacts 
angrily to that debasement and to the whole enterprise of Dante's tinkering with literature, language and style. Virgil's real motivation may be shown also by the fact that, in this case, he angrily intervenes when Dante is only passively watching a squabble, while he does not disapprove in the two other cases mentioned above where Dante actually is an active participant in the quarrels.

Virgil would seem to achieve a quick and easy victory over the humbled disciple as he harshly rebukes him. The very fact that Dante the author allows his alter ego in the poem to be so promptly overpowered and put to shame may testify to Dante's acknowledgement of the controversial character of his own experimentations and his uncertainty about the kind of welcome that would be reserved by most critics to the stylistic "promiscuity" of his poem. Even if the literary exchange with Giovanni del Virgilio is to come much later, Dante may already be aware of the hostility he would encounter in the cultured community. ${ }^{15}$ The first thing Dante must do in order to succeed in his literary enterprise is to strive to liberate himself from the tutelage of Virgil and of the classical examples. Perhaps the whole difficult relationship between Dante and Virgil throughout the Inferno and Purgatorio may stem, to some extent, from this very struggle.

We should remember that Dante himself has shown his concern with the problem of style in his writings, in particular in the De vulgari Eloquentia 2.4. As P. V. Mengaldo notes in the Introduction to his edition of $D v E$ (xxxvi-1), Dante's rhetorical culture derives mostly from the artes dictamini and the poetriae of the 12th and 13th centuries. ${ }^{16}$ These treatises in turn depend to a large extent on classical works such as the Rhetorica ad Herennium, Cicero's De Inventione and Horace's Ars Poetica. Dante knew these works and we can thus presume that he was influenced by them directly as well as through the medieval rhetoricians.

Geoffroi de Vinsauf states that the three styles, grandiloquus, mediocris and humilis, depend on the persons and things being written about (Documentum 3.145). John of Garland, tying the styles to the status hominum, elaborates the famous Rota Vergilii where Virgil's three chief works become the models for the three kinds: the Bucolics for the stylus humilis, the Georgics for the mediocris and the Aeneid for the gravis. Style becomes connected with social 
dignity and social class. As Faral notes, "c"est la qualité des personnes, et non plus celle de la locution, qui fournit le principe de la classification" (88). This of course represents a change by comparison with the Ciceronian doctrines as formulated, for instance, in the Rhetorica ad Herennium (4.8), where the three styles are exclusively defined by the choice of words used and by the presence or lack of ornaments. But, aside from the addition of a social dimension, the medieval classifications conform to the classical rules in prescribing a definite hierarchy of terms in the vocabulary adopted and a hierarchy of rhetorical figures divided between the ornatus difficilis and the ornatus facilis, to be applied according to the style aimed at. Without going into the details that would take us too far from the subject, let us only note that metaphor, metonymy, synecdoche, antithesis and periphrasis belong to the ornatus difficilis which of course characterizes the modus gravis. Conversely, the ornatus facilis, suitable for the two other styles, includes figures of speech such as the annominatio and figures of thought such as the simile. What is intriguing for our present subject is that, according to the medieval treatises, both the annominatio and the simile are to be shunned or, at least, used only very sparingly.

As is pointed out by Mengaldo, ${ }^{17}$ Dante, in his De vulgari Eloquentia $2.4 .5-7$, follows in theory the medieval tripartition of styles. But in practice, when discussing stylistic levels, Dante concentrates on the binary opposition between tragoedia and comoedia ( $E . D .5$ : $437 a)$, the first requiring a "superior" style or the illustris vernacular, the latter an "inferior" style which can fluctuate between the "mediocre" or "humble" ("quandoque mediocre, quandoque humile vulgare sumatur" 2.4.6). Mengaldo observes that "ciò che caratterizza maggiormente la posizione dantesca è precisamente il fatto che da questa fluttuazione sia esclusa proprio, a differenza che nella tradizione oraziana ortodossa, la tragedia, così isolata nella propria altezza" (437b). In his unfinished treatise, Dante indicates only the elements that should characterize the "tragic" style: "gravitas sententiarum," metric structure, "constructionis elatio et excellentia vocabulorum" (2.4.7). But in the Letter to Cangrande a case is made for a stylistic flexibility when Horace's Ars poetica 93-96 is quoted as allowing the authors of comedies to express themselves like the authors of tragedies and viceversa. ${ }^{18}$ It may be interesting to note that 
this passage has been cited by some critics as invalidating Dante's authorship of the Letter to Cangrande, since it contradicts the definition of the two styles (elate et sublime for the tragedy and remisse et humiliter for the comedy) given just before the reference to Horace. I would argue that on the contrary the citation of Horace would be in accord with the stylistic pluralism of the Commedia.

Particularly important in Dante's treatise on language is the notion of convenientia, that is, the relationship of suitability or congruence between style and subject (materia: res and persona). In other words the stylistic register must be appropriate to the persons and things dealt with. And to each of the styles there must be a correspondence of lexical choices.

This convenientia is exactly what we may notice as lacking in Inferno 30. To recapitulate, the initial simile, though it deals with persons and things of the loftiest kind, is worded in a simple mode which we may define as mediocris. The stylistic level then precipitously slides into the low both in content and in lexical choice, despite the fact that one of the two characters involved is Mirra, a tragic figure in her own right. The tone somehow goes up illogically for the humble figure of Griffolino who uses elegant terms and figures such as periphrases and annominationes. And when Master Adam speaks, an analogous inversion takes place as this petty counterfeiter is given a speech lofty both in lexicon and in rhetorical adornments. And while the altercation between Master Adam and Sinon is vulgar in tone and words, it is full of figures of speech such as the already mentioned antitheses, chiastic constructions, repetitions, periphrases and annominationes.

If we examine all these various sections of the canto, we may note that Dante departs here both from the medieval prescriptions about the accord between style and materia and from the classical rules concerning elocutio, that is the choice of vocabulary and rhetorical figures which should agree among themselves and with the stylistic level adopted. Dante mixes it all, using in the mouth of the same characters the high and the low lexicon, the ornatus facilis and the ornatus difficilis. He ignores the convenientia, he is apparently indifferent to any sense of consistency and to what is appropriate for a character or for the circumstances. If any canto should be chosen to embody the message Dante wanted to convey when he gave his 
poem the title of comedict, as well as the pluralism of styles he meant to adopt, this is canto 30 of the Inferno.

It has often been noted that cantos bearing the same number in the three canticas tend to have some kind of mutual correspondences, a development of similar themes, or a recurrence of analogous events. The similarities between cantos 30 in the Purgatorio and Paradiso are indisputable: in Purgatorio 30 Virgil disappears and Beatrice appears. In Paradiso 30 Beatrice makes her last appearance as Dante's guide, to be followed by St. Bernard. If we can see these events as making some sort of rite of passage-from the tutelage of Virgil to that of Beatrice, from the guidance of Beatrice to that of St. Bernard, higher and higher on the ladder of spiritual progress and enlightenment-is there anything similar in Inferno 30 to show a relationship with these other two cantos?

I believe that the rite of passage taking place in Inferno 30 has to do with Dante's emancipation from Virgil in the matter of style and language. He achieves independence on the strength of his newly claimed role as a Christian poet writing a truthful poem. We have already seen that in Inferno 29.58-64, when citing the regeneration of the population of Aegina from the seed of ants, Dante slyly interjects: "secondo che i poeti hanno per fermo." This assertion stands out as a deliberate, if implicit, denunciation of the blatant mendacity of the pagan poets who may be seen as analogous to the falsifiers encountered now by the two wayfarers. And, just before the reference to Ovid's myth, Dante, describing the tenth bolgia, specifies:

$$
\begin{aligned}
& \text {. . là 've la ministra } \\
& \text { de l'alto Sire infallibil giustizia } \\
& \text { punisce i falsador che qui registra. }
\end{aligned}
$$

Hollander convincingly makes the point that the "here" referred to in line 57 is the text of the Commedia itself, which therefore is not a common poem which could be just as false as any other product of a poet, but is "uniquely veracious" since divine justice herself registers in it the damned she punishes: "Justice, as God's minister, takes her place as the dittator of what will be recorded in the text by the agency of Dante's pen." Dante would thus be pitting himself as the scriba Dei or scriba lustitiae against the "pagan fabulators." Hollander also points out that this passage "constitutes perhaps [Dante's] first 
drawing back of the veil which conceals his identity as poet inspired by the Holy Spirit" ("Book of the Dead" 43-44).

Having thus made in canto 29 his first claim for the veracity of his poem, instrument of God's justice, Dante sets himself at the opposite pole of the pagan poets with their misleading poems and their "dei falsi e bugiardi." From this new exalted position, Dante proceeds in canto 30 to reject the literary authority of the classical poets and the lessons of their examples. He subverts the classification of styles, the sense of decorum and restraint, the appropriateness of what should be said by whom and how. He lays claim for full freedom of style, of language and of the uses of rhetoric for the new Christian poem. ${ }^{19}$ He freely borrows materials from Ovid and from Virgil, and adapting them for his own purposes, he undermines the meanings or imports they had in the original works. While Dante the character may temporarily be shamed into submission by the scolding master, in effect the Christian poet is revolting against Virgil as he had not hitherto dared to do. The text of canto 30 remains before us, displaying the full scope of its subversive enterprise, regardless of Virgil's rebuke.

It is also important to note that the scene closing canto 30 apparently leaves an aftermath of bitterness in Dante: at the beginning of canto 31, he compares Virgil's tongue-first biting him ("mi morse") in the rebuke and then offering a medicina-to Achilles' spear which wounded and then healed its cut (1-6). It is a rather strong image which shows how deeply hurt Dante felt. Moreover, that Virgil's conciliatory words have not really closed Dante's wound is demonstrated by the ensuing silence between the two travelers: they proceed "sanza alcun sermone" (9). Virgil would appear to sense that he is at fault because he does what he had not done since Inferno 3.19 , and 13.130, (and which he will not do again), namely, he takes Dante by the hand and does so in a much more affectionate manner than in the two previous occasions: "Poi caramente mi prese per mano" (28). In the two earlier cases, Virgil's gesture is a needed response to Dante's fears: the first time, in Inferno 3, Dante has just seen the inscription on the gate of hell and is obviously disheartened; the second time, in the wood of the suicides, he is so upset that he cannot speak to Pier delle Vigne (13.82-84) and his horror is increased by the pack of black bitches tearing to pieces the miserable 
sinners. In canto 31 conversely, there is no fear displayed by Dante to prompt Virgil's act (only later, when he sees that what he believed to be towers are in fact giants, does Dante say "fuggiemi errore e crescemi paura," (39). It could be argued that Virgil takes Dante by the hand anticipating his fright. But it also is very probable that Virgil is tacitly trying to make up for his earlier burst of anger.

Additional support for the thesis that the ending of canto 30 was not meant to be a recantation may be found in the manifold ways in which Dante continues to violate the separation of styles and the convenientia or to question implicitly the ethics of Virgil's high style and rhetoric. I shall mention just a few examples: in canto 31 Virgil is seen addressing the classical character Antaeus with a speech which is rather surprising in the blatant deceitfulness of its flattery (115-29). ${ }^{20}$ In canto 32 Dante claims the need for "rime aspre e chiocce" to speak of the last circle, but modestly denies having them. Paradoxically he uses low words such as "abbo," "pigliare a gabbo," "mamma o babbo" (5-9), which he had proscribed in the De vulgari Eloquentia 2.7. Yet, while saying that this is not the language apt for describing the bottom of the universe, he does not resort to the lofty style that would be the logically necessary alternative. The canto is actually full of "harsh and grating" words in a low register, and it ends in a brawl between Dante himself and Bocca degli Abati.

Skipping now many other similar instances, let me just cite in conclusion two of the most flagrant cases of inconvenientia. In Paradiso 30, in the Empyrean, Beatrice's very last speech to Dante before disappearing from his side is a not too elegant expression of anger predicting death and damnation for two popes. Even more strikingly, in the previous canto, she uses some 60 verses to attack the philosophers and preachers in a tone alternating between the high and the "comic," going as far as to exclaim (with echoes of Inf. 30.27?): "Di questo ingrassa il porco sant'Antonio, / e altri assai che sono ancor più porci, / pagando di moneta sanza conio" (Par. 29.12426). At first sight, these are astonishingly inappropriate words in the mouth of the blessed woman and in the heaven where God is visible as a resplendent point surrounded by the angelic choirs. Many commentators agree with Tommaseo's observation that "il cenno dei porci non è cosa degna di Beatrice e del Paradiso." 21 But it certainly conforms with Dante's linguistic and stylistic objectives as implicitly 
proclaimed in Inferno 30 and, I believe, is one more proof that Dante the author did not mean there to recant his "comic-realistic" style.

As many a time before and after Inferno 30, an apparently simple simile is used by Dante to make the reader pause and wonder at the reasons for its lack of correspondence to the context. Because of its incongruity, the simile calls attention to itself and to the whole canto. In a poem whose author demonstrably is in command of his means of expression, anything odd or inappropriate is probably meant to make some important point. In this case, what Dante aims at is, I believe, the justification for the very title of his poem and for his novel stylistic enterprise. Inferno 30 is Dante's battlecry for the independence he sought from the tyranny of classical examples and of the rhetoricians' rules. It is Dante's manifesto for his revolutionary "new style."

\section{NOTES}

1 "dira lues ira populi lunonis iniquae / incidit exosae dictas a paelice terras" (Met. 7.523-24).

2 "saevae memorem Iunonis ob iram" (Aen. 1.4).

3 "tantaene animis caelestibus irae?" (Aen. 1.11).

... veterisque memor Saturnia belli, prima quod ad Troiam pro caris gesserat Argis (necdum etiam causae irarum saevique dolores exciderant animo; manet alta mente repostum iudicium Paridis spretaeque iniuria formae, et genus invisum et rapti Ganymedis honores) ... .

(Aen. 1.23-28).

5 Bigi cites the symmetry in the syntactical structures as evidenced in the use of a temporal clause at the first tercet of each mythological episode ("Nel tempo che Iunone ... E quando la fortuna ..."); the naming of the protagonist in each of the second tercets ("Atamante . . Ecuba . . ."), etc.; he mentions the frequency of difficult rhymes and the accumulation of epithets for Hecuba ("trista, misera, cattiva, ... dolorosa, . . . forsennata") (1063-64).

6 In Convivio 4.27.17, Dante had already referred to the same Ovidian story as "favola." See Hollander, "Dante's 'Book of the Dead,' " esp. 32-33.

7 See M. Frankel, "Dante's Anti-Virgilian villanello (Inf. XXIV 1-21)."

8 Oddly enough, lines 64-72 also anticipate the punishment inflicted on the gluttons in Purgatorio 22 to 24, where, from the high rock fell "un liquor chiaro" which "si spandeva per le foglie suso" (22.137-38). Master Adam's words about the drying out of his face are echoed in the description of the gluttons in lines 22-27 of Purgatorio 23. And as Forese Donati explains to 
Dante:

\author{
... "De l'etterno consiglio \\ cade vertù nell'acqua $\mathrm{c}$ ne la pianta \\ rimasa dietro ond'io sì m'assottiglio.... \\ Di bere $\mathrm{c}$ di mangiar n'accende cura \\ l'odor ch'esce del pomo c de lo sprazzo... "
}

(23.61-63, 67-68)

It is of course somehow unexpected that in Hell, where matter counts so heavily, Master Adam may be tormented by a mere mental image of the water, while in the more spiritual Purgatory an actual water is needed to trigger the wasting thirst felt by the souls. But in any case there is an undeniable resemblance between the torments of Master Adam and those inflicted in the sixth circle upon Forese and the gluttons on the "monte ove ragion ne fruga" (Purg. 3.3), another echo of the counterfeiter's words (70).

9 Cf. Enciclopedia dantesca s. v. "Guidi," "Guidi, Aghinolfo II" and "Guidi, Alessandro" (3: 318b-20b).

10 We do not know, of course, when Inferno 30 was written, whether before or after the death of Henry VIl, and hence after the crumbling of Dante's hopes in the re-establishment of the empire. As it has been suggested in the case of Inferno 19.81-84, where Dante already knows about the death of Clement $V$ in 1314, he may have altered his text post-factum. I do not intend to engage here in a discussion about the dating of the Commedia which would bring me too far from the subject at hand. I am simply noting the surprisingly unfavorable attitude which Dante displays in this canto towards a family which had shared his expectations about Henry VII and from whose castles "sub fonte Sarni" he had written in 1311 his fiery Epistles in favor of or to the Emperor (6 and 7).

11 Colin Hardie has pointed out in a letter to me that Dante could easily have avoided the addition of a Biblical character to the already ample contaminatio of this canto by using the classical figure of Phaedra. Dante knew that Phaedra was guilty of the same sin of false charges of seduction as Potiphar's wife, since he refers to Hippolytus' stepmother as "spietata e perfida noverca" in Paradiso 17.46-48. The fact that he chose the unnamed Egyptian woman may show Dante's decision to make the mixture of different worlds and cultures as wide as possible. Incidentally, we may remark that in this line 97 we have the only reference to Joseph in the Commedia. This is perhaps a puzzling fact when we think that the Hebrew patriarch shares with the prophet Daniel the visionary power to forctell the future on the basis of dreams: a gift that should perhaps have made the two Biblical figures attractive to Dante in view of his own prophetic aspirations. Yet Dante never mentions Joseph again. And, while he does mention Daniel three times, he does so always in passing, giving him only scant attention (see Purg. 22.146-47, Par. 4.13-15, 29.134).

12 Colin Hardie reminded me that Virgil himsclf is not averse to the genre of the tenzone, as can be seen in the rather animated exchange between the two 
shepherds in Eclogue 3.1-27.

13 See, among others, Contini, "Dante come personaggio-poeta della Commedia" in Varianti.

14 That Virgil may also feel a certain disdain for Dante's own way of expressing himself may be revealed by his rather overbearing attitude in Inferno 26.72-75 where, not very tactfully, he tells Dante to refrain from speaking to Ulysses: "Lascia parlare a me, ch'i' concetto / ciò che tu vuoi; ch'ei sarebbero schivi, / perch'e' fuor greci, forse del tuo detto." Whatever the reasons for Virgil's imposed mediation, the use of the Greek language is not one of them, as otherwise Dante would not have been able to follow the exchange between Virgil and Ulysses. Rather, Virgil seems to imply that Dante's "detto" would not be elegant enough for the Greek heroes, in short, that Dante was incapable of adopting the high style which was necessary to elicit a response from Ulysses. In fact, when addressing the two Greek heroes, Virgil refers to the "alti versi" he had written in the world above (82).

$15 \mathrm{Cf}$. in particular Eg. 1.6-7, 15-22, 33-34 (from Giovanni del Virgilio to Dante); and Dante's answer to Giovanni's rebuke in Eg. 2.36-37, 52-54; and especially his proud claim about the richness, uniqueness and freedom from conventions of his poem: "ovis gratissima ... lactis abundans ... Nulli iuncta gregi nullis assuetaque caulis, / sponte venire solet, nunquam vi, poscere mulctram" (58-62).

16 In particular by Matthew de Vendôme, Geoffroi de Vinsauf and John of Garland. See Faral.

17 Introduction to De vulgari Eloquentia, and in Enciclopedia dantesca s. v. "stili, Dottrina degli," 5: 435a-438b. For a discussion of this subject, see also Hollander, Il Virgilio dantesco 117-25.

18 "sicut vult Oratius in sua Poetria, ubi licentiat aliquando comicos ut tragedos loqui, et sic et converso" (Ep. 13.30).

19 See on this subject Erich Auerbach's seminal essay "Sacrae Scripturae sermo humilis," originally published in 1944.

20 See Bosco's uneasy comment: "Per far di Anteo uno sciocco che si lascia imbrogliare dal discorsetto di Virgilio (che sarebbe dunque da interpretare tutto in chiave ironica) bisogna anzitutto ammettere che Virgilio sia disponibile all'imbroglio, laddove è chiaro che la sua alta nobiltà [non] gli permette . . . di trarre alcuno in inganno" (452).

21 For a typical example of the puzzlement felt by the critics, see Getto's comments: "la pagina che segue, tra le più violente del Paradiso [è] tra quelle che più lasciano perplesso il critico, posta com'è in bocca alla femminile Beatrice e alle soglic della visione di Dio ..." (1958): "Con queste immagini rudi di porci ingrassati e di monete senza conio lo sguardo del poeta si muove e fruga su un orizzonte brutalmente terreno. L'atmosfera celeste si è fatta estremamente remota ..." (1961-62); and more: "crude terrestrità," "qualcosa di stonato, che spezza la raffinata misura del Paradiso" (1962-63); "l'innegabile debolezza di questo luogo ... malgrado tutte le giustificazioni possibili, ri- 
mane come un vero e proprio difetto: perché quella disarmonia altro non è che mancanza di poesia e assenza di ispirazione." But Getto does admit that Dante's language is open "su ogni forma di vita" (1965).

\section{WORKS CITED}

Alighieri, Dante. La Divina Commedia. Inferno. Ed. Umberto Bosco and Giovanni Reggio. Firenze: Le Monnier, 1979.

. Inferno. Firenze: Sansoni, 1972. Vol. 1 of La Divina Commedia con i commenti di T. Casini-S. A. Barbi e di A. Momigliano. Ed. F. Mazzoni. 3 vols. 1972-74.

La Divina Commedia. Inferno. Ed. Natalino Sapegno. Firenze: La Nuova Italia, 1975.

. The Divine Comedy. Inferno 2: Commentary. Trans. with notes by Charles Singleton. Princeton: Princeton UP, 1970.

Auerbach, Erich. "Sacrae Scripturae sermo humilis." 1944. Studi su Dante. Ed.

D. Della Terza. Milano: Feltrinelli, 1963.

Bigi, Emilio. "Canto XXX." Lectura Dantis Scaligera. Inferno. Firenze: Le Monnier, 1971. 1063-86.

Contini, Gianfranco. "Sul XXX dell'Inferno." Varianti e altra linguistica. Una Raccolta di saggi (1938-1968). Torino: Giulio Einaudi, 1970. 447-457.

. "Dante come personaggio-poeta della Commedia." Varianti.

Faral, E. Les Arts poétiques du XIle et du XIIle siècle. Paris: Librairie Honoré Champion, 1962.

Frankel, Margherita. "Dante's Anti-Virgilian villanello (Inf. XXIV, 121)." Dante Studies 102 (1984): 81-109.

Getto, Giovanni. "Canto XXIX." Letture dantesche. Paradiso. Ed. G. Getto. Firenze: Sansoni, 1964.

Hollander, Robert. Il Virgilio dantesco: Tragedia nella Commedia. Firenze: Olschki, 1983.

"Dante's 'Book of the Dead:' A Note on Inferno XXIX 57." Studi Danteschi 54 (1982). 31-51.

Johnson, R. W. Darkness Visible. A Study of Vergil's Aeneid. Berkeley: U of California P, 1976.

Mengaldo, P. V., ed. De vulgari Eloquentia. By Dante. Padova: Editrice Antenora, 1968.

"stili, Dottrina degli." Enciclopedia dantesca. 6 vols. Roma: Instituto Enciclopedia Italiana, 1970-78. 5: 435-38.

Virgil. Eclogues. Georgics. Aeneid. Trans. H. Rushton Fairclough. Loeb Classical Library. Rev. ed. 2 vols. Cambridge: Harvard UP, 1978. 